Article

\title{
Using Spin-Coated Silver Nanoparticles/Zinc Oxide Thin Films to Improve the Efficiency of GaInP/(In)GaAs/Ge Solar Cells
}

\author{
Po-Hsun Lei *, I-Jen Chen, Jia-Jan Chen, Po-Chun Yang and Yan-Hua Gong
}

Institute of Electro-Optical and Materials Science, National Formosa University, 64 Wen-Hwa Rd, Hu-Wei, Yun-Lin 623, Taiwan; angelren1010@gmail.com (I.-J.C.); style_rx7@hotmail.com.tw (J.-J.C.); 10676124@gm.nfu.edu.tw (P.-C.Y.); 10676111@gm.nfu.edu.tw (Y.-H.G.)

* Correspondence: pohsunlei@gmail.com; Tel.: +886-5-6315668

Received: 29 May 2018; Accepted: 13 June 2018; Published: 15 June 2018

\begin{abstract}
We synthesized a silver nanoparticle/zinc oxide (Ag NP/ZnO) thin film by using spin-coating technology. The treatment solution for $\mathrm{Ag} \mathrm{NP} / \mathrm{ZnO}$ thin film deposition contained zinc acetate $\left(\mathrm{Zn}\left(\mathrm{CH}_{3} \mathrm{COO}\right)_{2}\right)$, sodium hydroxide $(\mathrm{NaOH})$, and silver nitrate $\left(\mathrm{AgNO}_{3}\right)$ aqueous solutions. The crystalline characteristics, surface morphology, content of elements, and reflectivity of the Ag $\mathrm{NPs} / \mathrm{ZnO}$ thin film at various concentrations of the $\mathrm{AgNO}_{3}$ aqueous solution were investigated using $\mathrm{X}$-ray diffraction, scanning electron microscopy, energy-dispersive X-ray spectroscopy, atomic force microscopy, and ultraviolet-visible-near infrared spectrophotometry. The results indicated that the crystalline structure, $\mathrm{Ag}$ content, and reflectance of $\mathrm{Ag} \mathrm{NP} / \mathrm{ZnO}$ thin films depended on the $\mathrm{AgNO}_{3}$ concentration. Hybrid antireflection coatings (ARCs) composed of $\mathrm{SiN}_{\mathrm{x}}$ and $\mathrm{Ag} \mathrm{NPs} / \mathrm{ZnO}$ thin films with various $\mathrm{AgNO}_{3}$ concentrations were deposited on GaInP/(In)GaAs/Ge solar cells. We propose that the optimal ARC consists of $\mathrm{SiN}_{\mathrm{x}}$ and $\mathrm{Ag} \mathrm{NP} / \mathrm{ZnO}$ thin films prepared using a treatment solution of $0.0008 \mathrm{M} \mathrm{AgNO}_{3}, 0.007 \mathrm{M} \mathrm{Zn}\left(\mathrm{CH}_{3} \mathrm{COO}\right)_{2}$, and $1 \mathrm{M} \mathrm{NaOH}$, followed by post-annealing at $200^{\circ} \mathrm{C}$. $\mathrm{GaInP} /(\mathrm{Al}) \mathrm{GaAs} / \mathrm{Ge}$ solar cells with the optimal hybrid ARC and $\mathrm{SiN}_{\mathrm{x}}$ ARC exhibit a conversion efficiency of $34.1 \%$ and $30.2 \%$ with $\mathrm{V}_{\mathrm{oc}}=2.39$ and $2.4 \mathrm{~V}, \mathrm{~J}_{\mathrm{sc}}=16.63$ and $15.37 \mathrm{~mA} / \mathrm{cm}^{2}$, and fill factor $=86.1 \%$ and $78.8 \%$.
\end{abstract}

Keywords: Ag NPs/zinc oxide thin film; InGaP/InGaAs/Ge solar cell; spin-coating technology

\section{Introduction}

Multi-junction solar cells (MJSCs) based on III-V compound semiconductors have attracted much attention for space and terrestrial applications because they are composed of inherently tunable and direct bandgap materials, resulting in a high conversion efficiency due to the absorption of a varied solar spectrum [1-3]. However, the conversion efficiency of MJSCs depends on not only the absorption but also the intensity of sunlight; consequently, MJSCs exhibit a lack of absorption under one-sun or low-concentration sunlight for terrestrial applications, and this causes low conversion efficiency. To enhance the absorption of the solar spectrum and obtain a high conversion efficiency, several studies have endeavored to optimize the solar cell structures of MJSCs by using various bandgap materials such as graded AlGaInP solar cells, $\mathrm{Ga}(\mathrm{In}) \mathrm{NAs}(\mathrm{Sb})$ solar cells, GaInP/GaInAsP/GaAs triple-junction solar cells, GaP/InGaAs/InGaSb triple-junction solar cells, GaInP-based multiple quantum well solar cells, and wafer-bonded InP-based four junction MJSCs [4-9]; in MJSCs, each junction is connected by a tunneling junction (TJ). In conventional III-V compound semiconductor-based MJSCs, the TJ is composed of heavily doped $\mathrm{p}-\mathrm{GaAs}$ and $\mathrm{n}-\mathrm{GaAs}$. Some studies have suggested that conventional GaAs TJs can be replaced with other Al-based materials such as GaInP/AlGaAs, GaAs/AlGaAs, 
or AlGaAs/AlGaAs, all of which can effectively improve device performance $[6,10,11]$. In addition to device structure design, antireflection coatings (ARCs) are usually applied to the tops of MJSCs to reduce surface reflection and enhance incident sunlight. A strong reflection occurs at the top cell-air interface because the III-V semiconductor has an inherently high refractive index and strongly disperses wavelengths below $500 \mathrm{~nm}$. The optimal thickness and refractive index of an ARC can be designed to have quarter-wavelength thickness and $\left(n_{a} \times n_{s}\right)^{1 / 2}$, where $n_{a}$ and $n_{s}$ are the refractive indices of the ambient environment and top cell, respectively. An ARC was proposed using graded- $\mathrm{SiO}_{2} / \mathrm{TiO}_{2}$ and a genetic algorithm to optimize the graded-SiO $\mathrm{O}_{2}$ layer [12]. An algorithm including material dispersion can minimize reflection in a wide range of wavelengths and under varied incident angles. A triple-layer ARC composed of $\mathrm{MgF}_{2}, \mathrm{HfO}_{2}$, and $\mathrm{TiO}_{2}$ or $\mathrm{SiC}$ was applied to the $\mathrm{GaAsP} / \mathrm{Si}$ double-junction solar cell [13]; the results indicated low reflection $(<5 \%)$ within the spectrum of $390 \mathrm{~nm}$ to $1000 \mathrm{~nm}$. A $\mathrm{ZnO}$ nanorod $/ \mathrm{TiO}_{2}$ ARC was deposited on InGaP/GaAs/Ge triple-junction solar cells to increase conversion efficiency [14]; compared with bare solar cells, the InGaP/GaAs/Ge triple-junction solar cells with $\mathrm{ZnO}$ nanorod $/ \mathrm{TiO}_{2} \mathrm{ARC}$ achieved a $30 \%$ enhancement in conversion efficiency. A $\mathrm{ZnO}$ nanowire ARC that incorporated an Al-doped $\mathrm{ZnO}(\mathrm{AZO})$ electrode was used in InGaP/GaAs/Ge $\mathrm{TJ}$ solar cells to reduce the reflectance of sunlight at the ARC-air interface [15]. The ZnO nanowire ARC combined with AZO can reduce reflectance in the short-wavelength range and achieve high conversion efficiency. Kang et al. [16] utilized coverglasses with hierarchical microstructured and subwavelength-structured surfaces to improve the absorption efficiency of InGaP/GaAs/Ge TJ solar cell modules. The short current density $\left(\mathrm{J}_{\mathrm{sc}}\right)$ and conversion efficiency of patterned coverglass-solar-cell modules were enhanced by $12.14 \%$ and $11.19 \%$, respectively, compared with those of a conventional solar cell module.

Numerous researchers have reported on the surface technologies that have been used in ARCs to enhance the conversion efficiency of solar cells. ARCs can improve the lack of absorption of MJSCs under one-sun or low-concentration sunlight for terrestrial applications, and then enhance the conversion efficiency of solar cells. Popular surface technologies include a photonic crystal (PC) structure, metal/dielectric-based localized surface plasmon (LSP) structure, and textured structure. PC structures are those where a periodic variation in the refractive index occurs on the scale of the light wavelength in one or more directions [17]. An ARC with the periodic refractive index of the PC structure can diffract the waveguide mode above a certain cutoff frequency; this can improve the reflection of incident sunlight. PC-structured ARCs can be fabricated as distributed Bragg reflectors (DBRs) [18], which have a patterned surface defined by Lloyd's mirror combined with a reactive ion etch (RIE) [19], a photolithograph-defined periodic structure [20], silicon dioxide nanospheres [21], patterned $\mathrm{ZnO}$ cavities [22], and polystyrene (PS)-defined $\mathrm{AZO}$ and $\mathrm{SiO} 2$ [23-25]. Surface plasmon coupling effects are the collective oscillations of electrons at the interface of a metal and a dielectric, and can be classified as surface plasmon polaritons at metal surfaces and the LSPs of local oscillation among isolated metallic nanostructures with resonant frequencies. LSP-coupling-affected ARCs are applied to solar cells because a solar cell with a metal surface is sheltered from the sunlight; they can be produced using silver (Ag) clusters or nanoparticles (NPs) on solar cell surfaces [26-29], Ag/indium-tin-oxide (ITO) [30], $\mathrm{Ag} / \mathrm{AZO}$ [31], and $\mathrm{ZnO} / \mathrm{Ag} / \mathrm{ZnO}$ [32]. Textured surface window layers with submicron morphology on solar cells can enhance conversion efficiency by improving the absorption of broadband and divergent sunlight. Texturing surfaces by etching with diluted acid [33], ultraviolet nanoimprint lithography [34], chemical vapor deposition in high vacuum chambers [35], and crafting a rough or modified surface from a low-surface-energy material to form a superhydrophobic surface [36] are effective and commonly used processing methods.

In this study, we synthesized a silver $\mathrm{NP} /$ zinc oxide (Ag NPs/ZnO) thin film by using spin-coating technology. The treatment solution for the Ag NPs/ZnO thin film was composed of zinc acetate $\left(\mathrm{Zn}\left(\mathrm{CH}_{3} \mathrm{COO}\right)_{2}\right)$, sodium hydroxide $(\mathrm{NaOH})$, and silver nitrate $\left(\mathrm{AgNO}_{3}\right)$ aqueous solutions. Spin-coating technology offers the advantages of low cost, a large growth area, good step coverage, simple deposition equipment, and ease of preparation. The morphology of the Ag NP/ZnO thin 
film was observed through a field emission scanning electron microscopy (FE-SEM, JEOL, Tokyo, Japan), and the film's Ag content was determined using energy-dispersive X-ray spectroscopy (EDS) (JSM-7500F, JEOL, Tokyo, Japan). The crystalline characteristics of the Ag NP/ZnO thin film were characterized by X-ray diffraction (XRD) patterns using an advanced diffractometer (Bruker D8, Billerica, MA, USA) equipped with CuKa $(\lambda=0.154 \mathrm{~nm})$. The root mean square (RMS) roughness of the Ag NP/ZnO film was analyzed using atomic force microscopy (AFM) (D13100, Digital instruments Veeco Metrology Group, Plainview, NY, USA). Finally, the Ag NPs/ZnO thin film was deposited on $\mathrm{SiN}_{\mathrm{x}}$-coated GaInP/GaAs/Ge solar cells. The current density versus voltage (JV) characteristics for completed solar cell chips were measured using a solar simulator with an Xe lamp light source calibrated to a one-sun condition. During JV measurements, the ambient temperature was controlled using a temperature control stage (STC200, Instec, Boulder, CO, USA). The Ag NPs/ZnO thin film with $\mathrm{SiN}_{\mathrm{x}}$ was used as a hybrid ARC to reduce the reflection of sunlight. The conversion efficiency and short current density of GaInP/GaAs/Ge solar cells with the optimal hybrid ARC constituted a substantial improvement over GaInP/GaAs/Ge solar cells with $\operatorname{SiN}_{x}$ ARCs.

\section{Results and Discussion}

The $\mathrm{Zn}\left(\mathrm{CH}_{3} \mathrm{COO}\right)_{2}$ aqueous solution composed of $\mathrm{Zn}^{2+}$ and $\mathrm{CH}_{3} \mathrm{COO}^{-}$ions was mixed with the $\mathrm{NaOH}$ aqueous solution containing $\mathrm{Na}^{+}$and $\mathrm{OH}^{-}$ions to form a $\mathrm{ZnO}$ treatment solution. Ions in the $\mathrm{ZnO}$ treatment solution reacted to form a $\mathrm{ZnO}$ thin film on the silicon nitride-coated $\left(\mathrm{SiN}_{\mathrm{x}}\right)$ glass (SNG) substrate through the following reaction:

$$
\begin{gathered}
\mathrm{Zn}\left(\mathrm{CH}_{3} \mathrm{COO}\right)_{2}+2 \mathrm{NaOH} \leftrightarrows \mathrm{Zn}^{2+}+2 \mathrm{CH}_{3} \mathrm{COONa}+2 \mathrm{OH}^{-} \\
\mathrm{Zn}^{2+}+4 \mathrm{OH}^{-} \leftrightarrows \mathrm{Zn}(\mathrm{OH})_{4}{ }^{2-} \\
\mathrm{Zn}(\mathrm{OH})_{4}{ }^{2-} \leftrightarrows \mathrm{Zn}(\mathrm{OH})_{2}+2 \mathrm{OH}^{-} \\
\mathrm{Zn}(\mathrm{OH})_{2} \leftrightarrows 2 \mathrm{H}^{+}+\mathrm{ZnO}_{2}{ }^{2-} \\
\mathrm{Zn}^{2+}+2 \mathrm{ZnO}_{2}{ }^{2-} \leftrightarrows \mathrm{ZnO}^{\prime}
\end{gathered}
$$

$\mathrm{AgNO}_{3}$ added to a $\mathrm{ZnO}$ treatment solution, as an $\mathrm{Ag} \mathrm{NP} / \mathrm{ZnO}$ treatment solution can thermally decompose into Ag NPs, gaseous oxynitride, and oxygen during the post-annealing process at $200{ }^{\circ} \mathrm{C}$, as indicated in the following reaction [28]:

$$
\mathrm{AgNO}_{3} \leftrightarrows 2 \mathrm{Ag}+2 \mathrm{NO}_{2}+\mathrm{O}_{2}
$$

Consequently, the Ag NP/ZnO thin film was obtained on the SNG substrate after spin-coating and the $200{ }^{\circ} \mathrm{C}$ post-annealing process.

Table 1 lists the $\mathrm{O}, \mathrm{Zn}$, and $\mathrm{Ag}$ contents of $\mathrm{ZnO}$ and $\mathrm{Ag} \mathrm{NP} / \mathrm{ZnO}$ thin films measured using EDS at $\mathrm{AgNO}_{3}$ concentrations of $0.005 \mathrm{M}, 0.008 \mathrm{M}, 0.02 \mathrm{M}$, and $0.05 \mathrm{M}$. The $\mathrm{Zn}^{2+}, \mathrm{Zn}(\mathrm{OH})_{4}{ }^{2-}, \mathrm{Zn}(\mathrm{OH})_{2}$, and $\mathrm{ZnO}_{2}{ }^{2-}$ ions in the $\mathrm{ZnO}$ treatment solutions reacted to form a $\mathrm{ZnO}$ thin film through the process expressed in Equations (2)-(5). The Ag content of the $\mathrm{Ag} \mathrm{NP} / \mathrm{ZnO}$ thin film increased when the $\mathrm{AgNO}_{3}$ concentration rose from $0.005 \mathrm{M}$ to $0.02 \mathrm{M}$, because large numbers of $\mathrm{Ag} \mathrm{NPs}$ developed in the $\mathrm{Ag} \mathrm{NP} / \mathrm{ZnO}$ thin film, according to Equation (6). Furthermore, the Ag content in the Ag NP/ZnO thin film increased with the $\mathrm{AgNO}_{3}$ concentration, but the $\mathrm{Zn}$ and $\mathrm{O}$ contents remained constant, implying the formation of $\mathrm{Ag}$ NPs rather than $\mathrm{AgO}$ or $\mathrm{Ag}_{2} \mathrm{O}$ in the $\mathrm{Ag} \mathrm{NP} / \mathrm{ZnO}$ thin film; $\mathrm{AgO}$ and $\mathrm{Ag}_{2} \mathrm{O}$ may form in a solution of $\mathrm{AgNO}_{3}$ mixed with $\mathrm{NaOH}$ [37].

To study the crystallization of Ag NPs on $\mathrm{ZnO}$ thin films, the XRD spectra of the Ag NP/ZnO thin films at various $\mathrm{AgNO}_{3}$ concentrations were measured, and are plotted in Figure 1. A preferential (002) peak $\left(34.4^{\circ}\right)$ alongside a (101) peak $\left(36.2^{\circ}\right)$ and $(100)$ peak $\left(31.8^{\circ}\right)$ was found in the spin-coated $\mathrm{ZnO}$ thin film, thereby indicating a hexagonal wurtzite structure and a polycrystalline nature. Similar XRD patterns were observed in spin-coated $\mathrm{Ag} \mathrm{NP} / \mathrm{ZnO}$ thin films with extra peaks of face-center-cubic crystal Ag, namely a (111) peak $\left(38.1^{\circ}\right)$ and (200) peak $\left(44.3^{\circ}\right)$. As depicted in Figure 1, the diffraction intensity of the $\mathrm{Ag}(111)$ and $\mathrm{Ag}$ (200) peaks gradually increased when the $\mathrm{AgNO}_{3}$ concentrations 
rose from $0 \mathrm{M}$ to $0.05 \mathrm{M}$ because of the increase in $\mathrm{Ag}$ content in the $\mathrm{Ag} \mathrm{NP} / \mathrm{ZnO}$ treatment solution, as indicated in Equation (6). Furthermore, no diffraction peak for $\mathrm{Ag}$ oxides such as $\mathrm{AgO}_{\text {or }} \mathrm{Ag}_{2} \mathrm{O}$ occurred (see Figure 1) because of decomposition of $\mathrm{Ag}$ oxide to $\mathrm{Ag}$ and $\mathrm{O}_{2}$ during the $200{ }^{\circ} \mathrm{C}$ post-annealing process [32]. Ag NP reduction at an $\mathrm{AgNO}_{3}$ concentration of $0.005 \mathrm{M}$ is rare in an Ag NP/ZnO treatment solution, because the low $\mathrm{AgNO}_{3}$ concentration engenders low diffraction intensity and a wide pattern of $\mathrm{Ag}$ (111) and (200) peaks. As the $\mathrm{AgNO}_{3}$ concentration increased from $0.008 \mathrm{M}$ to $0.05 \mathrm{M}$, a large quantity of Ag NPs formed in the treatment solution; consequently, these small-sized NPs aggregated at the surface or interfaced between $\mathrm{ZnO}$ grains, and gathered to a large grain size of Ag NPs during the post-annealing process, resulting in an enhanced diffraction intensity and narrow pattern of $\mathrm{Ag}$ (111) and Ag (200) peaks. In addition, the intensity of the $\mathrm{ZnO}-(100)$-indexed diffraction peak increased, whereas that of the $\mathrm{ZnO}$-(002)-indexed diffraction peak decreased with the rising $\mathrm{AgNO}_{3}$ concentration; this was attributed to the (002)-orientated $\mathrm{ZnO}$ thin films being destroyed or bended by the large numbers of $\mathrm{Ag}$ NPs at a high $\mathrm{AgNO}_{3}$ concentration [38].

Table 1. $\mathrm{O}, \mathrm{Zn}$, and $\mathrm{Ag}$ contents of $\mathrm{ZnO}$ and $\mathrm{Ag}$ nanoparticle (NP)/ZnO thin films.

\begin{tabular}{cccc}
\hline $\mathbf{A g N O}_{3}$ Concentration (M) & O Content (at \%) & Zn Content (at \%) & Ag Content (at \%) \\
\hline 0 & 70.02 & 29.98 & 0 \\
0.005 & 70.2 & 29.4 & 0.4 \\
0.008 & 70.3 & 29.1 & 0.61 \\
0.02 & 69 & 30.2 & 0.8 \\
0.05 & 73.7 & 24.8 & 1.51 \\
\hline
\end{tabular}

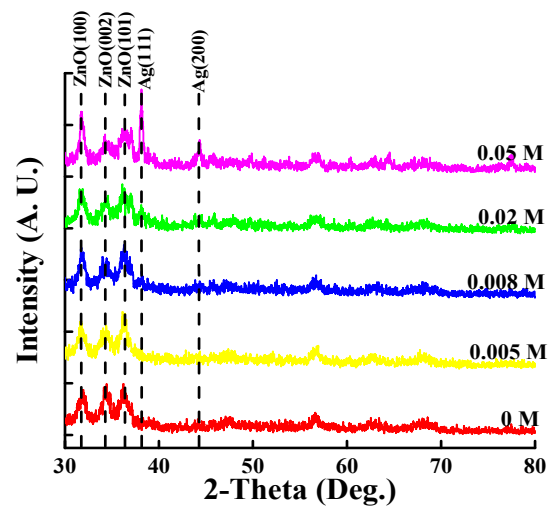

Figure 1. X-ray diffraction (XRD) spectra of spin-coated $\mathrm{ZnO}$ thin films and Ag NP/ZnO thin films with various $\mathrm{AgNO}_{3}$ concentrations.

The surface morphologies of the $\mathrm{ZnO}$ and $\mathrm{Ag} \mathrm{NP} / \mathrm{ZnO}$ thin films were examined based on scanning electron microscopy (SEM) images. Figure 2 depicts top-view images of the $\mathrm{ZnO}$ and $\mathrm{Ag} \mathrm{NP} / \mathrm{ZnO}$ thin films at various $\mathrm{AgNO}_{3}$ concentrations on SNG substrates. According to Equations (1)-(5), the ZnO thin films without Ag NPs were able to develop, and then formed on the SNG substrate after spin-coating and the post-annealing process; the surface morphology of the $\mathrm{ZnO}$ thin film was textured and rough, as depicted in Figure 2a. A textured $\mathrm{ZnO}$ thin film can serve as an $\mathrm{ARC}$ to reduce reflectivity in the GaInP/GaAs/Ge triple-junction solar cell [39]. Figure 2b depicts the $\mathrm{Ag} \mathrm{NP} / \mathrm{ZnO}$ thin film prepared with an $\mathrm{AgNO}_{3}$ concentration of $0.005 \mathrm{M}$. A small grain size and rare distribution of Ag NP were observed and are depicted in Figure 2b; the rare distribution was attributable to the small number of Ag NPs in the treatment solution, and the small grain size was attributed to the incomplete gathering of Ag NPs under a post-annealing temperature of $200{ }^{\circ} \mathrm{C}$; a rare distribution of Ag NPs cannot effectively reduce the reflection of sunlight for solar cell applications [27,39,40]. Although the grain size and distribution of Ag NPs on Ag NP/ZnO thin films can be improved by increasing the post-annealing temperature, a high annealing temperature will 
rise the reflectivity of $\mathrm{Ag} \mathrm{NP} / \mathrm{ZnO} / \mathrm{SiN}_{\mathrm{x}}$ hybrid thin films, as shown in Figure $2 \mathrm{f}$, possibly due to the larger grain sizes of the Ag NPs. In order to achieve a small interval between two Ag NPs and large-grain-sized Ag NP on Ag NP/ZnO thin films without raising the post-annealing temperature, an $\mathrm{Ag} \mathrm{NP} / \mathrm{ZnO}$ treatment solution with a high $\mathrm{AgNO}_{3}$ concentration can be used to deposit $\mathrm{Ag}$ $\mathrm{NP} / \mathrm{ZnO}$ on thin films. Figure 2c-e depict top-view SEM images of Ag NP/ZnO thin films on an SNG substrate prepared with $\mathrm{AgNO}_{3}$ concentrations of $0.008 \mathrm{M}, 0.02 \mathrm{M}$, and $0.05 \mathrm{M}$. When the $\mathrm{AgNO}_{3}$ concentration increased to $0.008 \mathrm{M}$, a small interval between two Ag NPs on Ag NP/ZnO thin films was achieved after the post-annealing process, because of the large number of Ag NPs in the Ag $\mathrm{NP} / \mathrm{ZnO}$ treatment solution. However, the distribution and grain size of the Ag NPs on the Ag $\mathrm{NP} / \mathrm{ZnO}$ thin films depicted in Figure 2d,e were rarer and larger than those depicted in Figure 2c. A high (>0.008 M) $\mathrm{AgNO}_{3}$ concentration in the $\mathrm{Ag} \mathrm{NP} / \mathrm{ZnO}$ treatment solution led to a large quantity of Ag NPs and short spaces between Ag NPs; these factors can enhance the gathering of Ag NPs on $\mathrm{Ag} \mathrm{NP} / \mathrm{ZnO}$ thin films during the post-annealing process. Consequently, the interval between two Ag $\mathrm{NPs}$ and the grain size of the $\mathrm{Ag} \mathrm{NPs}$ on the $\mathrm{Ag} \mathrm{NP} / \mathrm{ZnO}$ thin films grown at $\mathrm{AgNO}_{3}$ concentrations of $0.02 \mathrm{M}$ and $0.05 \mathrm{M}$ were larger than those grown with an $\mathrm{AgNO}_{3}$ concentration of $0.008 \mathrm{M}$.

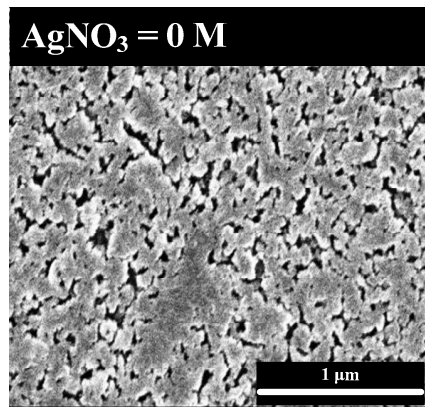

(a)

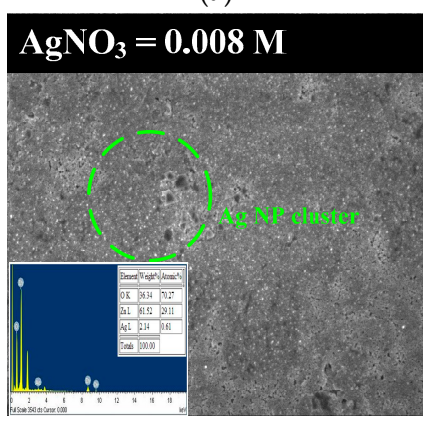

(c)

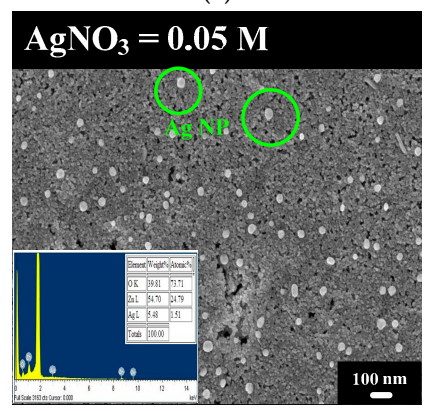

(e)

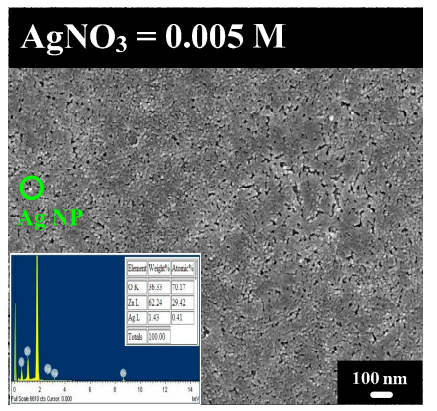

(b)

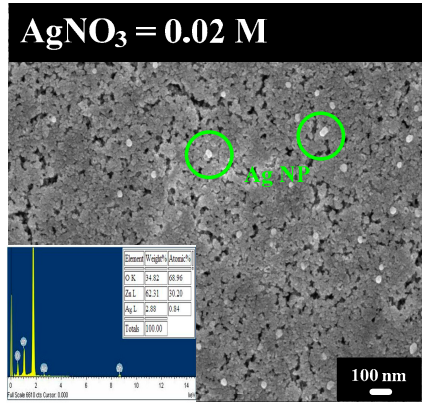

(d)

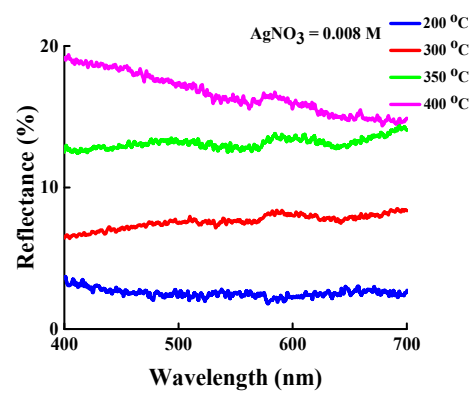

(f)

Figure 2. SEM images for (a) spin-coated $\mathrm{ZnO}$ and silver nanoparticle/zinc oxide (Ag NP/ZnO) grown at $\mathrm{AgNO}_{3}$ concentrations of $(\mathbf{b}) 0.005 \mathrm{M}$, (c) $0.008 \mathrm{M},(\mathbf{d}) 0.02 \mathrm{M}$, and (e) $0.05 \mathrm{M}$; the inset of (b-e) are the energy-dispersive X-ray spectroscopy (EDS) spectra. (f) is the reflectivity of $\mathrm{Ag} \mathrm{NP} / \mathrm{ZnO} / \mathrm{SiN}_{\mathrm{x}}$ hybrid thin films grown at various post-annealing temperatures. 
Figure 3 depicts the RMS roughness of the $\mathrm{Ag} \mathrm{NP} / \mathrm{ZnO}$ thin film as a function of $\mathrm{Ag} \mathrm{NO}_{3}$ concentration; the insets of Figure 3 present AFM images of the Ag NP/ZnO thin films prepared with $\mathrm{AgNO}_{3}$ concentrations of $0.008 \mathrm{M}, 0.02 \mathrm{M}$, and $0.05 \mathrm{M}$. The RMS roughness of the Ag NP/ZnO thin films increased when the $\mathrm{AgNO}_{3}$ concentration rose from $0.005 \mathrm{M}$ to $0.008 \mathrm{M}$, and increased rapidly for the $\mathrm{Ag} \mathrm{NP} / \mathrm{ZnO}$ thin films grown at $\mathrm{AgNO}_{3}$ concentrations above $0.008 \mathrm{M}$. A large quantity of $\mathrm{Ag} \mathrm{NPs}$ were present in the $\mathrm{Ag} \mathrm{NP} / \mathrm{ZnO}$ treatment solution with a high $\mathrm{AgNO}_{3}$ concentration, according to Equation (6), and these Ag NPs ripened to a large grain size during the post-annealing process, which led to high RMS roughness. The AFM images of the Ag NP/ZnO thin films indicate a weak textured surface morphology at an $\mathrm{AgNO}_{3}$ concentration of $0.008 \mathrm{M}$, but strong textured surface morphologies at $\mathrm{AgNO}_{3}$ concentrations of $0.02 \mathrm{M}$ and $0.05 \mathrm{M}$. These textured $\mathrm{Ag} \mathrm{NP} / \mathrm{ZnO}$ thin films can be used as window layers of solar cells to enhance light trapping.

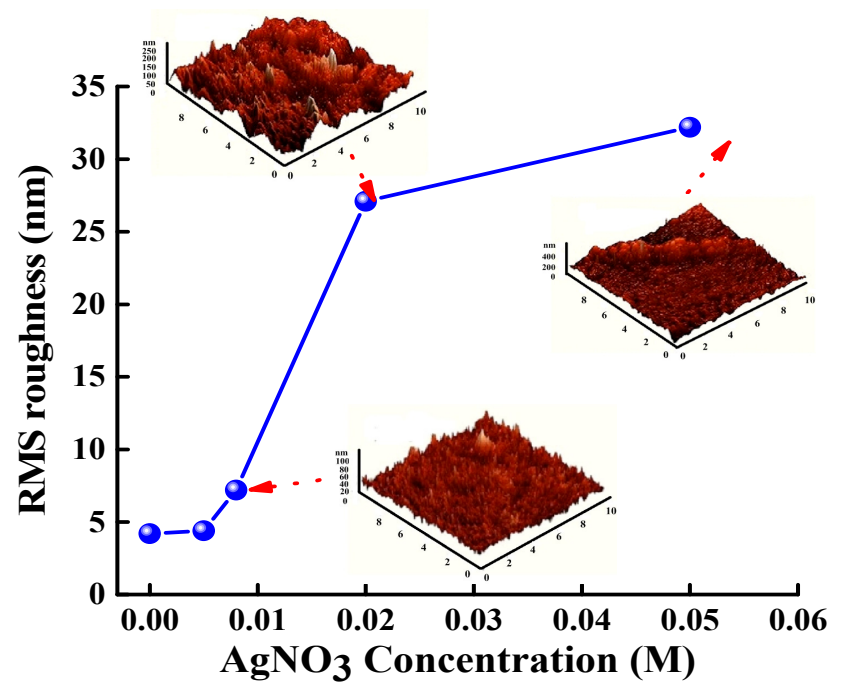

Figure 3. Root mean square (RMS) roughness of $\mathrm{Ag} \mathrm{NP} / \mathrm{ZnO}$ thin films as a function of $\mathrm{AgNO}_{3}$ concentration; the insets show atomic force microscopy (AFM) images of $\mathrm{Ag} \mathrm{NP} / \mathrm{ZnO}$ thin films prepared with $\mathrm{AgNO}_{3}$ concentrations of $0.008 \mathrm{M}, 0.02 \mathrm{M}$, and $0.05 \mathrm{M}$.

Figure 4 depicts the reflectivity of the $\mathrm{Ag} \mathrm{NP} / \mathrm{ZnO} / \mathrm{SiN}_{\mathrm{x}}$ hybrid thin film (named "hybrid $\mathrm{ARC}^{\text {") }}$ grown at varied $\mathrm{AgNO}_{3}$ concentrations as a function of wavelength over 400-700 nm. The average reflectivity of the hybrid $\mathrm{ARCs}_{\text {grown }} \mathrm{AgNO}_{3}$ concentrations of $0.005 \mathrm{M}, 0.008 \mathrm{M}, 0.02 \mathrm{M}$, and $0.05 \mathrm{M}$ were $2.99 \%, 2.67 \%, 2.53 \%, 5.99 \%$, and $7.47 \%$, respectively, all of which were lower than the reflectivity of the $\mathrm{SiN}_{\mathrm{x}}$ ARC (approximately 9.2\%) obtained in our previous study [39]. The effective refractive index $\left(\mathrm{n}_{\mathrm{eff}}\right)$ of the hybrid ARC is approximately 1.87 , and can be calculated using the following equation:

$$
\mathrm{n}_{\mathrm{eff}}=\frac{2}{\frac{1}{\mathrm{n}_{\mathrm{ZnO}}}+\frac{1}{\mathrm{n}_{\mathrm{SiNx}}}}
$$

where $\mathrm{n}_{\mathrm{ZnO}}$ (1.76) and $\mathrm{n}_{\mathrm{SiNx}}(2.0)$ are the refractive indices of $\mathrm{Ag} \mathrm{NP} / \mathrm{ZnO}$ and $\mathrm{SiN}_{\mathrm{x}}$ thin films, respectively. The calculated refractive index of the ARC $\left(\mathrm{n}_{\mathrm{ARC}}\right)$ is approximately 1.84 , which can be calculated from $\mathrm{n}_{\mathrm{ARC}}=\left(1 \times \mathrm{n}_{\mathrm{GaAs}}\right)^{1 / 2}$, where $\mathrm{n}_{\mathrm{GaAs}}$ is the refractive index of GaAs. The refractive index of the hybrid ARC (1.87) is closer to 1.84 than is $\operatorname{SiN}_{x}(2.0)$, leading to low reflectivity. The amplitude of reflectance $\left(\mathrm{r}_{\mathrm{APZN}}\right)$ and reflectivity $\left(\mathrm{R}_{\mathrm{APZN}}\right)$ between air and $\mathrm{Ag} \mathrm{NP} / \mathrm{ZnO}$ thin films are provided in [41] and expressed as follows:

$$
\mathrm{r}_{\mathrm{APZN}}=\frac{\mathrm{n}_{\mathrm{ZnO}}-1}{\mathrm{n}_{\mathrm{ZnO}}+1} \exp \left[-\frac{1}{2}\left(\frac{4 \pi \sigma \mathrm{n}_{\mathrm{ZnO}}}{\lambda}\right)\right]
$$




$$
\mathrm{R}_{\mathrm{APZN}}=\left|\frac{\mathrm{n}_{\mathrm{ZnO}}-1}{\mathrm{n}_{\mathrm{ZnO}}+1} \exp \left[-\frac{1}{2}\left(\frac{4 \pi \sigma \mathrm{n}_{\mathrm{ZnO}}}{\lambda}\right)\right]\right|^{2},
$$

where $\sigma$ is the RMS roughness of the $\mathrm{Ag} \mathrm{NP} / \mathrm{ZnO}$ thin film, and $\lambda$ is the wavelength of light in a vacuum. The reflectivity of the $\mathrm{Ag} \mathrm{NP} / \mathrm{ZnO}$ thin film decreased when the $\mathrm{AgNO}_{3}$ concentration increased from $0 \mathrm{M}$ to $0.008 \mathrm{M}$; this was attributable to the increasing RMS roughness depicted in Figure 3. However, the reflectivity of the $\mathrm{Ag} \mathrm{NP} / \mathrm{ZnO}$ thin films increased when the $\mathrm{AgNO}_{3}$ concentration increased from $0.02 \mathrm{M}$ to $0.05 \mathrm{M}$; this was attributable to the potent light scattering that resulted from the large grain size of Ag NPs evident in the SEM and AFM images.

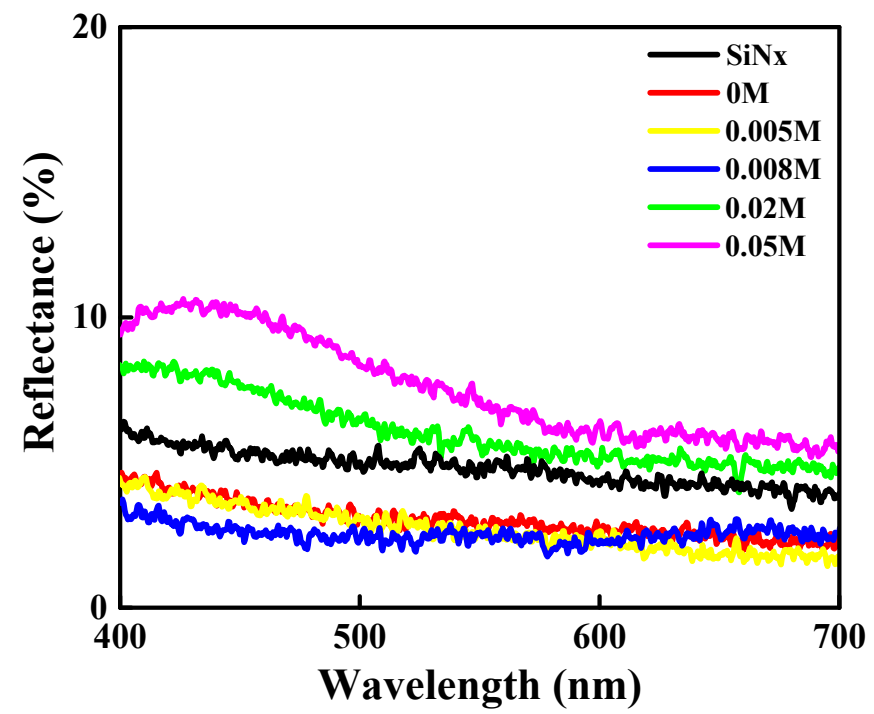

Figure 4. Reflectivity of the $\mathrm{Ag} \mathrm{NP} / \mathrm{ZnO} / \mathrm{SiN}_{\mathrm{x}}$ hybrid thin films grown at various $\mathrm{AgNO}_{3}$ concentrations as a function of wavelengths of $400-700 \mathrm{~nm}$.

Figure 5 depicts the JV characteristics of the GaInP/(In)GaAs/Ge solar cells with the $\mathrm{SiN}_{\mathrm{x}} \mathrm{ARC}$ and the $\mathrm{Ag} \mathrm{NP} / \mathrm{ZnO} / \mathrm{SiN}_{\mathrm{x}}$ hybrid $\mathrm{ARC}$ grown at $\mathrm{AgNO}_{3}$ concentrations of $0 \mathrm{M}, 0.005 \mathrm{M}, 0.008 \mathrm{M}$, $0.02 \mathrm{M}$, and $0.05 \mathrm{M}$. The inset of Figure 5 indicates the conversion efficiency of the GaInP/(In)GaAs/Ge solar cells with related ARCs. The short-circuit current density of the GaInP/(In)GaAs/Ge solar cells with $\mathrm{SiN}_{\mathrm{x}} \mathrm{ARC}$ and hybrid $\mathrm{ARC}$ grown at $\mathrm{AgNO}_{3}$ concentrations of $0 \mathrm{M}, 0.005 \mathrm{M}$, and $0.008 \mathrm{M}$ were $15.37 \mathrm{~mA} / \mathrm{cm}^{2}, 15.39 \mathrm{~mA} / \mathrm{cm}^{2}, 15.43 \mathrm{~mA} / \mathrm{cm}^{2}$, and $16.63 \mathrm{~mA} / \mathrm{cm}^{2}$. A high light-trapping effect achieved through a reduction in the surface reflectivity of GaInP/(In)GaAs/Ge solar cells is required to obtain a high short-circuit current density and conversion. Compared with the $\operatorname{SiN}_{\mathrm{x}}$ ARC, the hybrid ARC with a lower surface reflectivity enhanced the short-circuit current density of the GaInP/(In)GaAs/Ge solar cell because of the high transmitting intensity of sunlight into the solar cell. Moreover, the short-circuit current density of the GaInP/(In)GaAs/Ge solar cell with an $\mathrm{Ag} \mathrm{NP} / \mathrm{ZnO} \mathrm{ARC}$ grown at an $\mathrm{AgNO}_{3}$ concentration of $0.008 \mathrm{M}$ noticeably increased; this was attributable to the low surface reflectivity and high light trapping. The short-circuit current densities of the GaInP/(In)GaAs/Ge solar cells with $\mathrm{Ag} \mathrm{NP} / \mathrm{ZnO} \mathrm{ARC}$ grown at $\mathrm{AgNO}_{3}$ concentrations of $0.02 \mathrm{M}$ and $0.05 \mathrm{M}$ decreased to $15.54 \mathrm{~mA} / \mathrm{cm}^{2}$ and $14.79 \mathrm{~mA} / \mathrm{cm}^{2}$, respectively; these findings were attributable to the high surface reflectivity and light scattering that resulted from the large grain size of the Ag NPs. In this study, the conversion efficiency of a solar cell depended on the short-circuit current density because the open-circuit voltage and fill factor were fairly constant. As depicted in the inset of Figure 5, the GaInP/(In)GaAs/Ge solar cell with an Ag NP/ZnO ARC grown at an $\mathrm{AgNO}_{3}$ concentration of $0.008 \mathrm{M}$ demonstrated a maximum conversion efficiency of $34.17 \%$ because of the high short-circuit current density. 


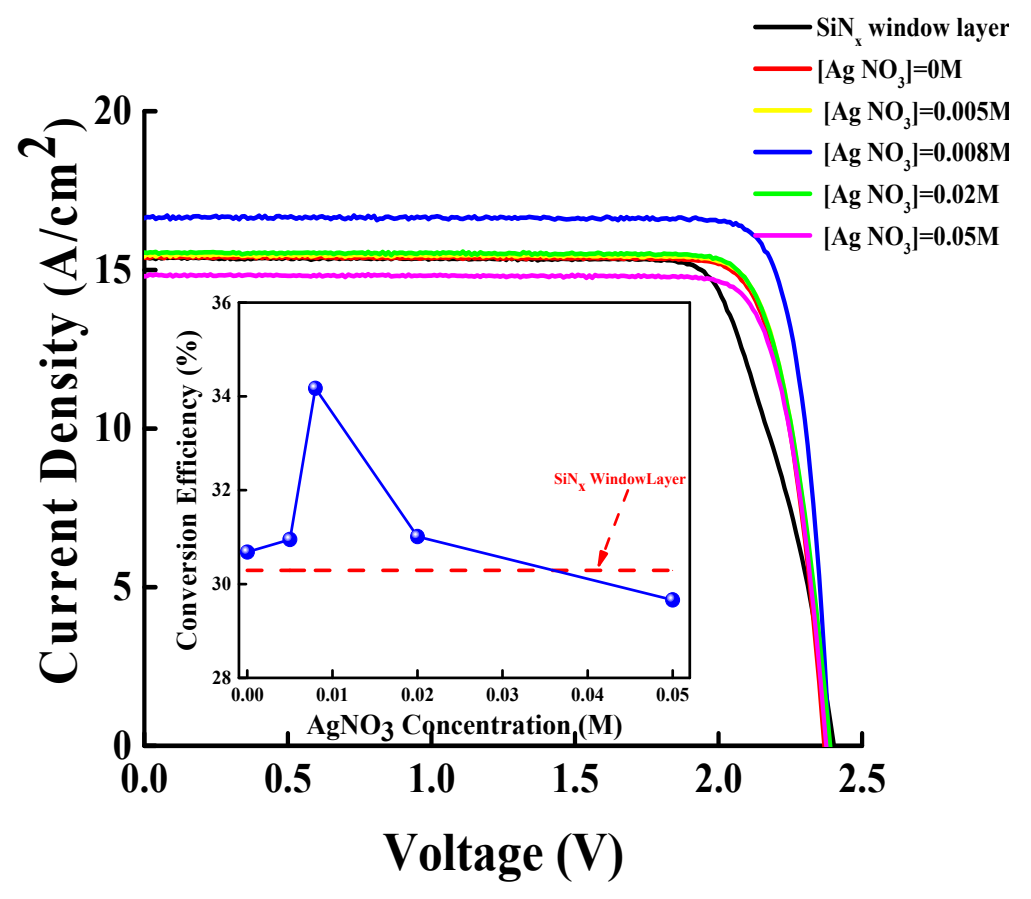

Figure 5. Current density versus voltage (JV) characteristics of GaInP/(In)GaAs/Ge solar cells with the $\mathrm{Ag} \mathrm{NP} / \mathrm{ZnO} / \mathrm{SiN}_{\mathrm{x}}$ hybrid antireflection coatings (ARCs) grown at $\mathrm{AgNO}_{3}$ concentrations of $0.005 \mathrm{M}$, $0.008 \mathrm{M}, 0.02 \mathrm{M}$, and $0.05 \mathrm{M}$; the inset indicates the conversion efficiency of GaInP/(In)GaAs/Ge solar cells with related ARCs.

Spin-coating is a method for synthesizing Ag NP/ZnO thin films through a chemical reaction in an aqueous solution at room temperature. According to the XRD (Figure 1) and SEM (Figure 2) images, and EDS analysis (Table 1), the Ag content and Ag NP grain size of $\mathrm{Ag} \mathrm{NP} / \mathrm{ZnO} / \mathrm{SiN}_{\mathrm{x}}$ hybrid ARCs depend on the $\mathrm{AgNO}_{3}$ concentration in treatment solution; Ag NPs in the treatment solution are in the form of clusters on the surface of $\mathrm{ZnO}$ thin films or at the interfaces between $\mathrm{ZnO}$ grains during the post-annealing process. The RMS roughness of $\mathrm{Ag} \mathrm{NP} / \mathrm{ZnO} / \mathrm{SiN}_{\mathrm{x}}$ hybrid ARCs related to the grain size of $\mathrm{Ag}$ NPs determines the surface reflectivity; the reflectivity of $\mathrm{Ag} \mathrm{NP} / \mathrm{ZnO} / \mathrm{SiN}_{\mathrm{x}}$ hybrid ARCs can be adjusted by $\mathrm{AgNO}_{3}$ concentration. Table 2 shows the measured short-circuit current density, open-circuit voltage, fill factor, and conversion efficiency of GaInP/(In)GaAs/Ge solar cells with varied ARCs. The highest conversion efficiency of $34.17 \%$ can be observed in Table 2 with the textured Ag $\mathrm{NP} / \mathrm{ZnO} / \mathrm{SiN}_{\mathrm{x}}$ hybrid ARC proposed by an $\mathrm{AgNO}_{3}$ concentration of $0.008 \mathrm{M}$. The RMS roughness of an $\mathrm{Ag} \mathrm{NP} / \mathrm{ZnO} / \mathrm{SiN}_{\mathrm{x}}$ hybrid ARC below $7.2 \mathrm{~nm}$ (with an $\mathrm{AgNO}_{3}$ concentration of $0.005 \mathrm{M}$ ) cannot effectively reduce the surface reflection, as indicated in Equation (9); the RMS roughness of the Ag $\mathrm{NP} / \mathrm{ZnO} / \mathrm{SiN}_{\mathrm{x}}$ hybrid $\mathrm{ARC}$, which is higher than $7.2 \mathrm{~nm}$ (with an $\mathrm{AgNO}_{3}$ concentration of $0.02 \mathrm{M}$ or $0.05 \mathrm{M}$ ), shows a low reflectivity; the Ag NP with large grain sizes causes high reflection and light scattering.

Table 2. Short-circuit current density ( $\left.\mathrm{J}_{\mathrm{SC}}\right)$, open-circuit voltage $\left(\mathrm{V}_{\mathrm{OC}}\right)$, fill factor, and conversion efficiency of GaInP/(In)GaAs/Ge solar cells with related ARCs (AM 0, 1 sun).

\begin{tabular}{|c|c|c|c|c|}
\hline ARC & $\mathrm{JSC}_{\mathrm{SC}}\left(\mathrm{mA} / \mathrm{cm}^{2}\right)$ & $\mathrm{V}_{\mathrm{OC}}(\mathrm{V})$ & Fill Factor (\%) & Conversion Efficiency (\%) \\
\hline $\operatorname{SiN}_{x}$ & 15.37 & 2.4 & 78.8 & 30.2 \\
\hline $\operatorname{Ag} \mathrm{NP}(0 \mathrm{M}) / \mathrm{ZnO} / \mathrm{SiN}_{\mathrm{x}}$ & 15.39 & 2.37 & 83.1 & 30.26 \\
\hline $\mathrm{Ag} \mathrm{NP}(0.005 \mathrm{M}) / \mathrm{ZnO} / \mathrm{SiN}_{\mathrm{x}}$ & 15.43 & 2.38 & 84.2 & 30.95 \\
\hline $\mathrm{Ag} \mathrm{NP}(0.008 \mathrm{M}) / \mathrm{ZnO} / \mathrm{SiN}_{\mathrm{x}}$ & 16.63 & 2.39 & 86.1 & 34.17 \\
\hline $\mathrm{Ag} \mathrm{NP}(0.02 \mathrm{M}) / \mathrm{ZnO} / \mathrm{SiN}_{x}$ & 15.54 & 2.39 & 83.5 & 31.01 \\
\hline $\mathrm{Ag} \mathrm{NP}(0.05 \mathrm{M}) / \mathrm{ZnO} / \mathrm{SiN}_{\mathrm{x}}$ & 14.79 & 2.38 & 84.4 & 29.76 \\
\hline
\end{tabular}




\section{Experimental Details}

\subsection{Deposition of the Ag NP/ZnO Thin Film}

The Ag NP/ $\mathrm{ZnO}$ treatment solution consisted of zinc acetate $\left(\mathrm{Zn}\left(\mathrm{CH}_{3} \mathrm{COO}\right)_{2}\right)$, sodium hydroxide $(\mathrm{NaOH})$, and silver nitrate $\left(\mathrm{AgNO}_{3}\right)$ aqueous solutions. $\mathrm{Zn}\left(\mathrm{CH}_{3} \mathrm{COO}\right)_{2}$ and $\mathrm{AgNO} \mathrm{NO}_{3}$ were used as the raw materials for preparing zinc oxide $(\mathrm{ZnO})$ and silver NPs (Ag NPs), and $\mathrm{NaOH}$ was used as a reductant. Since the solubility levels of $\mathrm{Zn}\left(\mathrm{CH}_{3} \mathrm{COO}\right)_{2}, \mathrm{NaOH}$, and $\mathrm{AgNO}_{3}$ powder in de-ionized (DI) water differed, these powders were dissolved in DI water individually to form aqueous solutions with $0.007 \mathrm{M}, 1 \mathrm{M}$, and $0.005-0.1 \mathrm{M}$ concentrations under room temperature. These solutions were then mixed and stirred uniformly to form an $\mathrm{Ag} \mathrm{NP} / \mathrm{ZnO}$ treatment solution at room temperature. Before the Ag NP/ZnO treatment solution was spread on the silicon nitride-coated $\left(\mathrm{SiN}_{\mathrm{x}}\right)$ glass $(\mathrm{SNG})$ substrate and the GaInP/GaAs/Ge solar cell with an $\mathrm{SiN}_{\mathrm{x}}$ layer, the surfaces of these substrates were treated using an oxygen plasma to obtain a hydrophilic surface. The substrates were baked on a hot plate at $100{ }^{\circ} \mathrm{C}$ for three minutes for dewatering after the $\mathrm{Ag} \mathrm{NP} / \mathrm{ZnO}$ treatment solution had been spread on the substrates via the spin-coating process. Finally, the dewatered SNG substrate and $\mathrm{GaInP} / \mathrm{GaAs} / \mathrm{Ge}$ solar cell with an $\mathrm{SiN}_{\mathrm{x}}$ layer were coated with the Ag NP/ZnO treatment solution and treated through a post-annealing process at $200{ }^{\circ} \mathrm{C}$ for $1 \mathrm{~h}$ in an $\mathrm{N}_{2}$-ambient furnace to form the Ag NP/ZnO thin film.

\subsection{Fabrication of GaInP/GaAs/Ge Solar Cells with an Ag NP/ZnO Window Layer}

GaInP and (In)GaAs were grown on 150- $\mu \mathrm{m}$ thick p-type Ge substrate through metal-organic chemical vapor deposition (MOCVD). The TJs used to link the Ge substrate, InGaAs, and GaInP subcells were heavily doped with n-GaAs/p-GaAs and p-AlGaAs/n-GaInP. An alloy composed of $\mathrm{Au} / \mathrm{Zn} / \mathrm{Ag} / \mathrm{Au}$ was coated onto the back of the $\mathrm{p}$-Ge substrate as a p-type contact metal. The wafer was successively patterned using a standard photolithographic process to define the n-contact region through partial exposure of n-InGaAs. An alloy composed of $\mathrm{AuGe} / \mathrm{Ni} / \mathrm{Au}$ was used as an n-type contact metal in the $n$-InGaAs contact region. Finally, an $\mathrm{Si}_{3} \mathrm{~N}_{4}(\mathrm{n}=2.0)$ grown through plasma-enhanced chemical vapor deposition and an Ag NP/ZnO thin film were coated onto n-AlInP, which was defined through partially etched n-InGaAs.

\section{Conclusions}

We proposed an Ag NP/ZnO thin film on an SNG substrate and a GaInP/(Al)GaAs/Ge solar cell created using spin-coating technology. The grain size and content of Ag on the Ag NP/ZnO thin film depended on the $\mathrm{AgNO}_{3}$ concentration in the $\mathrm{Ag} \mathrm{NP} / \mathrm{ZnO}$ treatment solution. An optimal hybrid ARC comprising $\mathrm{SiN}_{\mathrm{x}}$ and $\mathrm{Ag} \mathrm{NP} / \mathrm{ZnO}$ thin film grown with an $\mathrm{Ag} \mathrm{NP} / \mathrm{ZnO}$ treatment solution contained $0.0008 \mathrm{M} \mathrm{AgNO}_{3}, 0.007 \mathrm{M} \mathrm{Zn}\left(\mathrm{CH}_{3} \mathrm{COO}\right)_{2}$, and $1 \mathrm{M} \mathrm{NaOH}$; following the $200{ }^{\circ} \mathrm{C}$ post-annealing process; this ARC exhibited a lower average reflectivity (2.53\%) over wavelengths of 400-700 nm compared with the conventional $\mathrm{SiN}_{\mathrm{x}}$ ARC. This finding was attributable to the textured surface, as determined by the grain size of the Ag NPs, the $\mathrm{ZnO}$ surface morphology, and a suitable effective refractive index constructed of $\mathrm{SiN}_{\mathrm{x}}$ and $\mathrm{Ag} \mathrm{NP} / \mathrm{ZnO}$. GaInP/(Al)GaAs/Ge solar cells incorporating the optimal hybrid ARC demonstrated a high conversion efficiency rate of $34.1 \%$, with $\mathrm{V}_{\mathrm{oc}}=2.39 \mathrm{~V}, \mathrm{~J}_{\mathrm{sc}}=16.63 \mathrm{~mA} / \mathrm{cm}^{2}$, and fill factor $=86.1 \%$. Furthermore, well scale-defined and uniform-distributed Ag NPs are required in an $\mathrm{Ag} \mathrm{NP} / \mathrm{ZnO} / \mathrm{SiN}_{\mathrm{x}}$ hybrid ARC to reduce the reflectivity of GaInP/(Al)GaAs/Ge solar cells for industrial-scale application. An adjusted spinner speed and controlled drop volume of treatment solution would be the method for fulfilling the aforementioned requirements.

Author Contributions: This research was designed and analyzed by P.-H.L. The experimental process was perform by I.-J.C. and J.-J.C. The data collection was performed by P.-C.Y. and Y.-H.G.

Funding: This research was funded by the Ministry of Science and Technology, R. O. C. (106-2221-E-150-055-).

Conflicts of Interest: The authors declare no conflicts of interest. 


\section{References}

1. Luque, A.; Hegedus, S. Handbook of Photovoltaic Science and Engineering; John \& Wiley: New York, NY, USA, $2003 ;$ p. 359.

2. Green, M.A.; Emery, K.; Hishikawa, Y.; Warta, W.; Dunlop, E.D. Solar cell efficiency tables (version 47). Prog. Photovolt. Res. Appl. 2016, 24, 3-11. [CrossRef]

3. Nelson, J. The Physics of Solar Cells; Imperial College Press: London, UK, 2003; p. 198.

4. Faucher, J.; Sun, Y.; Jung, D.; Martin, D.; Masuda, T.; Lee, M.L. High-efficiency AlGaInP solar cells grown by molecular beam epitaxy. Appl. Phys. Lett. 2016, 109, 172105. [CrossRef]

5. Polojarvi, V.; Aho, A.; Tukiainen, A.; Schramm, A.; Guina, M. Comparative study of defect levels in GaInNAs, GaNAsSb, and GaInNAsSb for high-efficiency solar cells. Appl. Phys. Lett. 2016, 108, 122104. [CrossRef]

6. Sugaya, T.; Nagato, Y.; Okano, Y.; Oshima, R.; Tayagaki, T.; Makita, K.; Matsubara, K. Growth of InGaAsP solar cells and their application to triple-junction top cells used in smart stack multijunction solar cells. J. Vac. Sci. Technol. B 2017, 35, 02B103-1-02B103-5. [CrossRef]

7. Tiwari, B.; Hossain, M.J.; Bhattacharya, I. GaP/InGaAs/InGaSb triple junction current matched photovoltaic cell with optimized thickness and quantum efficiency. Sol. Energy 2016, 135, 618-624. [CrossRef]

8. Hashem, I.E.; Carlin, C.Z.; Hagar, B.G.; Colter, P.C.; Bedair, S.M. InGaP-based quantum well solar cells: Growth, structural design, and photovoltaic properties. J. Appl. Phys. 2016, 119, 095706. [CrossRef]

9. Dimroth, F.; Tibbits, T.N.D.; Niemeyer, M.; Predan, F.; Beutel, P.; Karcher, C.; Oliva, E.; Siefer, G.; Lackner, D.; Fuß-Kailuweit, P.; et al. Four-junction wafer-bonded concentrator solar cells. IEEE J. Photovolt. 2016, 6, 343-349. [CrossRef]

10. Sahoo, G.S.; Nayak, P.P.; Mishra, G.P. An ARC less InGaP/GaAs DJ solar cell with hetero tunnel junction. Superlattices Microstruct. 2016, 95, 115-127. [CrossRef]

11. Özen, Y.; Akın, N.; Kınacı, B.; Özçelik, S. Performance evaluation of a GaInP/GaAs solar cell structure with the integration of AlGaAs tunnel junction. Sol. Energy Mater. Sol. Cell 2015, 137, 1-5. [CrossRef]

12. Schubert, M.F.; Mont, F.W.; Chhajed, S.; Poxson, D.J.; Kim, J.K.; Schubert, E.F. Design of multilayer antireflection coatings made from co-sputtered and low-refractive-index materials by genetic algorithm. Opt. Exp. 2008, 16, 5290-5298. [CrossRef]

13. Saylan, S.; Milakovich, T.; Hadi, S.A.; Nayfeh, A.; Fitzgerald, E.A.; Dahlem, M.S. Multilayer antireflection coating design for $\mathrm{GaAs}_{0.69} \mathrm{P}_{0.31} / \mathrm{Si}$ dual-junction solar cells. Sol. Energy 2015, 122, 76-86. [CrossRef]

14. Tsai, M.T.; Yang, Z.P.; Jing, T.S.; Hsieh, H.H.; Yao, Y.C.; Lin, T.Y.; Chen, Y.F.; Lee, Y.J. Achieving graded refractive index by use of $\mathrm{ZnO}$ nanorods $/ \mathrm{TiO}_{2}$ layer to enhance omnidirectional photovoltaic performances of InGaP/GaAs/Ge triple-junction solar cells. Sol. Energy Mater. Sol. Cell 2015, 136, 17-24. [CrossRef]

15. Chang, S.J.; Hou, J.L.; Hsueh, T.J.; Lam, K.T.; Li, S.G.; Liu, C.H.; Chang, S.P. Triple-Junction GaInP/GaAs/Ge Solar Cells with an AZO Transparent Electrode and ZnO Nanowires. IEEE J. Photovolt. 2013, 3, 331-336. [CrossRef]

16. Kang, E.K.; Yeo, C.I.; Kang, S.J.; Min, J.W.; Song, Y.M.; Lee, Y.T. Improved Light Absorption of GaInP/GaAs/Ge Solar Cell Modules with Micro/Nanoengineered Coverglasses. IEEE J. Photovolt. 2015, 5, 1130-1136. [CrossRef]

17. Joannopoulos, J.D.; Meade, R.D.; Win, J.N. Photonic Crystals; Princeton University Press: Princeton, NJ, USA, 1995.

18. Yu, W.J.; Shen, L.; Long, Y.B.; Shen, P.; Guo, W.B.; Chen, W.Y.; Ruan, S.P. Highly efficient and high transmittance semitransparent polymer solar cells with one-dimensional photonic crystals as distributed Bragg reflectors. Org. Electron. 2014, 15, 470-477. [CrossRef]

19. Saravanan, S.; Dubey, R.S. Optical absorption enhancement in $40 \mathrm{~nm}$ ultrathin film silicon solar cells assisted by photonic and plasmonic modes. Opt. Commun. 2016, 377, 65-69. [CrossRef]

20. Huang, M.J.; Yang, C.R.; Lee, H.S.; Liu, H.L. Fabrication of novel hybrid antireflection structures for solar cells. Sol. Energy 2014, 107, 489-494. [CrossRef]

21. Luo, Q.; Deng, X.S.; Zhang, C.X.; Yu, M.D.; Zhou, X.; Wang, Z.B.; Chen, X.H.; Huang, S.M. Enhancing photovoltaic performance of perovskite solar cells with silica nanosphere antireflection coatings. Sol. Energy 2018, 169, 128-135. [CrossRef] 
22. Cheng, K.; Jin, R.R.; Liu, J.J.; Liu, X.S.; Liu, J.L.; Lu, Z.B.; Liu, Y.; Guo, L.F.; Du, Z.L. Patterned honeycomb-like $\mathrm{ZnO}$ cavities for $\mathrm{Cu}(\mathrm{In}, \mathrm{Ga}) \mathrm{Se}_{2}$ thin film solar cells with omnidirectionally enhanced light harvesting. Sol. Energy Mater. Sol. Cells 2017, 170, 211-218. [CrossRef]

23. Voroshilov, P.M.; Simovski, C.R.; Belov, P.A.; Shalin, A.S. Light-trapping and antireflective coatings for amorphous Si-based thin film solar cells. J. Appl. Phys. 2015, 117, 203101. [CrossRef]

24. Wang, P.H.; Nowak, R.E.; Geißendörfer, S.; Vehse, M.; Reininghaus, N.; Sergeev, O.; von Maydell, K.; Brolo, A.G.; Agert, C. Cost-effective nanostructured thin-film solar cell with enhanced absorption. Appl. Phys. Lett. 2014, 105, 183106. [CrossRef]

25. Wang, Y.Y.; Zhang, R.Y.; Zhang, Z.; Qiu, B.C.; Wang, S.M.; Wu, X.M. Efficiency improvement of GaInP solar cells by broadband omnidirectional antireflection through dielectric composite nanostructures. Sol. Energy Mater. Sol. Cell 2017, 169, 33-39. [CrossRef]

26. Tong, C.; Yun, J.Y.; Song, H.M.; Gan, Q.Q.; Anderson, W.A. Plasmonic-enhanced Si Schottky barrier solar cells. Sol. Energy Mater. Sol. Cells 2014, 120, 591-595. [CrossRef]

27. Liu, W.; Wang, X.D.; Li, Y.Q.; Geng, Z.X.; Yang, F.H.; Li, J.M. Surface plasmon enhanced GaAs thin film solar cells. Sol. Energy Mater. Sol. Cells 2011, 95, 693-698. [CrossRef]

28. Zhou, Z.Q.; Qiu, Y.; Shi, W.; Sun, T.; Li, Y.L.; Lu, M. Surface plasmons on Ag clusters induced via ultrasonic and thermal treatments and the enhancement of Si nanocrystal light emission. Physica E 2014, 64, 63-67. [CrossRef]

29. Sardana, S.K.; Chava, V.S.N.; Komarala, V.K. Morphology and optical properties of sputter deposited silver nanoparticles on plain, textured and antireflection layer coated textured silicon. Appl. Surf. Sci. 2015, 347, 651-656. [CrossRef]

30. Mandal, P.; Sharma, S. Progress in plasmonic solar cell efficiency improvement: A status review. Renew. Sustain. Energy Rev. 2016, 65, 537-552. [CrossRef]

31. Feng, Y.Y.; Zhou, H.P.; Xiang, Y.; Ji, H.; Chang, X.H.; Wang, C. Pronounced optical gain attained in Ag/AZO structure for solar cell applications. Mater. Lett. 2016, 178, 18-22. [CrossRef]

32. Xu, T.N.; Hu, L.; Jin, S.Q.; Zhang, B.P.; Cai, X.K.; Wu, H.Z.; Sui, C.H. Photon energy conversion via localized surface plasmons in ZnO/Ag/ZnO nanostructures. Appl. Surf. Sci. 2012, 258, 5886-5891. [CrossRef]

33. Kluth, O.; Schope, G.; Hupkes, J.; Agashe, C.; Muller, J.; Rech, B. Modified thornton model for magnetron sputtered zinc oxide: Film structure and etching behavior. Thin Solid Film 2003, 442, 80-85. [CrossRef]

34. Escarre, J.; Soderstrom, K.; Battaglia, C.; Haug, F.J.; Ballif, C. High fidelity transfer of nanometric random textures by UV embossing for thin film solar cells applications. Sol. Cell 2011, 95, 881-886. [CrossRef]

35. Loffler, J.; Groenen, R.; Linden, J.L.; van Sanden, M.C.M.; Schropp, R.E.I. Amorphous silicon solar cells on natively textured ZnO grown by PECVD. Thin Solid Film 2001, 392, 315-319. [CrossRef]

36. Mehmood, U.; Al-Sulaiman, F.A.; Yilbas, B.S.; Salhi, B.; Ahmed, S.H.A.; Hossain, M.K. Super hydrophobic surfaces with antireflection properties for solar applications: A critical review. Sol. Energy Mater. Sol. Cells 2016, 157, 604-623. [CrossRef]

37. Xie, J.S.; $\mathrm{Wu}$, Q.S. One-pot synthesis of $\mathrm{ZnO} / \mathrm{Ag}$ nanospheres with enhanced photocatalytic activity. Mater. Lett. 2010, 64, 389-392. [CrossRef]

38. Shan, G.Y.; Zheng, S.J.; Chen, S.P.; Chen, Y.W.; Liu, Y.C. Multifunctional ZnO/Ag nanorod array as highly sensitive substrate for surface enhanced Raman detection. Colloid Surf. B. Biointerfaces 2012, 94, 157-162. [CrossRef] [PubMed]

39. Lei, P.H.; Lin, C.T.; Ye, S.J. Improved Efficiency of GaInP/(In)GaAs/Ge Solar Cells Using Textured Liquid-phase-deposited (LPD) ZnO. J. Phys. D Appl. Phys. 2012, 46, 125105. [CrossRef]

40. Hou, Y.D.; Li, S.H.; Ye, S.; Zhang, M.G.; Shi, R.Y.; Du, J.L.; Du, C.L. Using self-assembly technology to fabricate silver particle array for organic photovoltaic devices. Microelectron. Eng. 2012, 98, 428-432. [CrossRef]

41. Poruba, A.; Fejfar, A.; Remes, Z.; Springer, J.; Vanecek, M.; Kocka, J. Optical absorption and light scattering in microcrystalline silicon thin films and solar cell. J. Appl. Phys. 2000, 88, 148-160. [CrossRef]

(C) 2018 by the authors. Licensee MDPI, Basel, Switzerland. This article is an open access article distributed under the terms and conditions of the Creative Commons Attribution (CC BY) license (http:/ / creativecommons.org/licenses/by/4.0/). 